Editorial

\title{
Advances in field methods for the study of Benthic Boundary Layer (BBL) biodiversity
}

Volume I Issue 2 - 2014

\section{Editorial}

The marine sediment-water interface is one of the most clearly defined ecological boundaries and the most extensive habitat on the planet occupying $75 \%$ of the Earth's surface. The ecological processes which appear to link the domain below the sediment-water interface with that above are likely to have global importance. However, the study of the different ecosystem structure above and below the sediment-water interface usually requires different hypotheses and methodological approaches leading often to scientific isolation of the two domains. Consequently, the role of biodiversity related to sediment-water interface is underestimated, especially in studies of benthic-pelagic coupling related to energy fluxes and also in holistic approaches of the marine ecosystem. At the interface between the sediment and the overlying water there is a benthic boundary layer (BBL) which is characterized by strong gradients of flow as well as high concentrations of dissolved and particulate matter. ${ }^{1}$ This dynamic zone can be extended from a few centimetres to tens of metres, depending both temporally and spatially on various physical and biogeochemical processes whereby organisms on either side of the sediment-water interface interact. Hyperbenthos constitutes the dominant BBL faunal component and includes all swimming bottomdependent organisms (mainly crustaceans) which perform, with varying amplitude, intensity and regularity, seasonal or daily vertical migrations into the water column. ${ }^{2}$ The BBL also supports epibenthic and several infaunal species emerging into the water column as well as zooplanktonic species usually derived from downward extensions. ${ }^{3}$ Most of the BBL species are considered to be key taxa in marine food webs. ${ }^{4}$ They exploit a large diversity of food resources, mobilizing organic and detritus particles and associated microbes or preying on meiobenthos and plankton, while constituting an important food source for demersal fish, epibenthic crustaceans and cephalopods. For the study of BBL macrofauna, specially designed samplers, generally known as hyperbenthic sledges, have been used over the last 40 years. Nevertheless, there are still practical technical difficulties in sampling efficiently the lowest layer of the water column above the seabed where most of these organisms are concentrated.

In the framework of an EU-funded project, a new sampling technique has been designed, developed and applied experimentally in the field for the study of BBL habitat focusing mainly on the sampling of macrofauna as well as the measurement of relevant physical and biogeochemical parameters. ${ }^{5-7}$ This novel sampling technique included, as a complementary application, a specially designed facility attached in the frontal part of a modified hyperbenthic sledge for the artificial resuspension of the surface sediment. This facility provided additional quantitative information on the BBL macrofaunal populations concentrated in the lowermost layer of the water column, just above the seabed surface, allowing a more comprehensive view of the role of this particular macrofauna in the marine food web to be built. A first set of experiments was carried out successfully in the field and the application of this different methodological approach gave new insights towards a better understanding of the role of BBL

\author{
Koulouri P \\ Institute of Marine Biology, Biotechnology \& Aquaculture, \\ Hellenic Centre for Marine Research Greece \\ Correspondence: P. Koulouri, Institute of Marine Biology, \\ Biotechnology \& Aquaculture, Hellenic Centre for Marine \\ Research Heraklion, Crete, Greece, Email yol72@hcmr.gr \\ Received: December 22, 2014 | Published: December 23, \\ 2014
}

biodiversity with respect to nutrient regeneration, carbon cycling and energy transfer to higher tropic levels. ${ }^{8-13}$ Despite its successful application the system has been upgraded in the framework of an EU excellence program (MARBIGEN, FP7-REGPOT-2010-1, www. marbigen.org), which aimed at supporting research infrastructures for marine biodiversity and genomics in the Eastern Mediterranean. The upgraded system is currently being applied in the framework of another project funded by the Greek General Secretariat for Research $\&$ Technology. One of the objectives of this project is to investigate the presence of benthic microalgal populations over extended parts of the oligotrophic continental shelf (in depths even deeper than $100 \mathrm{~m}$ ) of the eastern Mediterranean since the evidence that there is enough sunlight to support them, and especially benthic diatoms, is strong. $7,9,11,13$ The existence of relatively large populations of these benthic primary producers may overturn the view that most of the shallow un-vegetated benthic communities act only as heterotrophic systems, e.g. annual respiration and mineralization exceeds photosynthesis. Furthermore, the verification of this hypothesis may have important consequences for functioning of shelf ecosystem because relatively high benthic primary productivity is expected to affect the exchange of nutrients and oxygen across the sediment-water interface, to constitute a major food resource for BBL macrofaunal organisms, to moderate benthic carbon flows and finally to affect sediment stability.

\section{Acknowledgments}

None.

\section{Conflicts of interest}

None.

\section{References}

1. Boudreau BP, Jorgensen BB. The Benthic Boundary Layer. Transport Processes and Biogeochemistry. Oxford University Press, New York. 2001;pp.404. 
2. Brunel P, Besner M, Messier D, et al. Le traineau Macer-GIROQ: appareil ameliore pour l'echantillonnage quantitatif de la petite faune nageuse au voisinage du fond. Internationale Revueder gesamtenHydrobiologieund Hydrographie. 1978;63(6):815-829.

3. Dauvin JC, Vallet C. The Near-bottom layer as an ecological boundary in marine ecosystems: diversity, taxonomic composition and community definitions. Hydrobiologia. 2006;555(1):49-58.

4. Mees J, Jones MB. The Hyperbenthos. Oceanography and Marine Biology: An annual review. 1997;35:221-255.

5. Dounas CG, Davies IM, Hayes PJ, et al. Development of a new method for the quantitative measurement of the effect of otter trawling on benthic nutrient fluxes and sediment biogeochemistry. European Commission, Study Project Number 99/036, Final Technical Report, HCMR, Heraklion, Crete, Greece. 2002.

6. Koulouri P, Dounas C, Eleftheriou A. A new apparatus for the direct measurement of otter trawling effects on the epibenthic and hyperbenthic macrofauna. Journal of the Marine Biological Association U.K. 2003;83:1363-1368.

7. Dounas C. A new apparatus for the direct measurement of the effects of otter trawling on benthic nutrient releases. Journal of Experimental Marine Biology and Ecology. 2006;339(2):251-259.

8. Dounas C, Davies I, Hayes P, et al. The effect of different types of otter trawl groundrope on benthic nutrient fluxes and sediment biogeochemistry. American Fisheries Society Symposium. 2005;41:539544.
9. Dounas C, Davies I, Triantafyllou G, et al. Large-scale impacts of bottom trawling on shelf primary productivity. Continental Shelf Research. 2007;27:2198-2210.

10. Koulouri P, Dounas C, Eleftheriou A, Preliminary results on the effect of otter trawling on hyperbenthic communities in Heraklion Bay (Eastern Mediterranean, Cretan Sea). American Fisheries Society Symposium. 2005;41:529-537.

11. Koulouri P, Dounas C, Radin F, et al. Near-bottom zooplankton in the continental shelf and upper slope of Heraklion Bay (Crete, Greece, Eastern Mediterranean): observations on vertical distribution patterns. Journal of Plankton Research. 2009;31(7):753-762.

12. Koulouri P. Benthic Boundary Layer (BBL) Macrofaunal Communities Structure Over Oligotrophic Continental Shelves: A New Field Methodological Approach. In: Scanlon L \& Ranieri JL (Eds.), Continental Shelf: Geographical Distribution, Biota and Ecological Significance, Nova Science Publishers. 2013;pp.209.

13. Koulouri P, Dounas C, Eleftheriou A. Hyperbenthic community structure over oligotrophic continental shelves and slopes: Crete (South Aegean Sea, NE Mediterranean). Estuarine, Coastal and Shelf Science. 2013;117(20):188-198. 